\begin{tabular}{c} 
Volume and Issues Obtainable at Center for Sustainability Research and Consultancy \\
Journal of Accounting and Finance in Emerging Economies \\
ISSN: 2519-0318 ISSN (E) 2518-8488 \\
Volume 7: Issue 1 March 2021 \\
CSRC \\
Journal homepage: $\underline{\text { www.publishing.globalcsrc.org/jafee }}$ \\
\hline
\end{tabular}

\title{
Board Gender Diversity and Corporate Expropriations: Evidence from Pakistan Stock Exchange
}

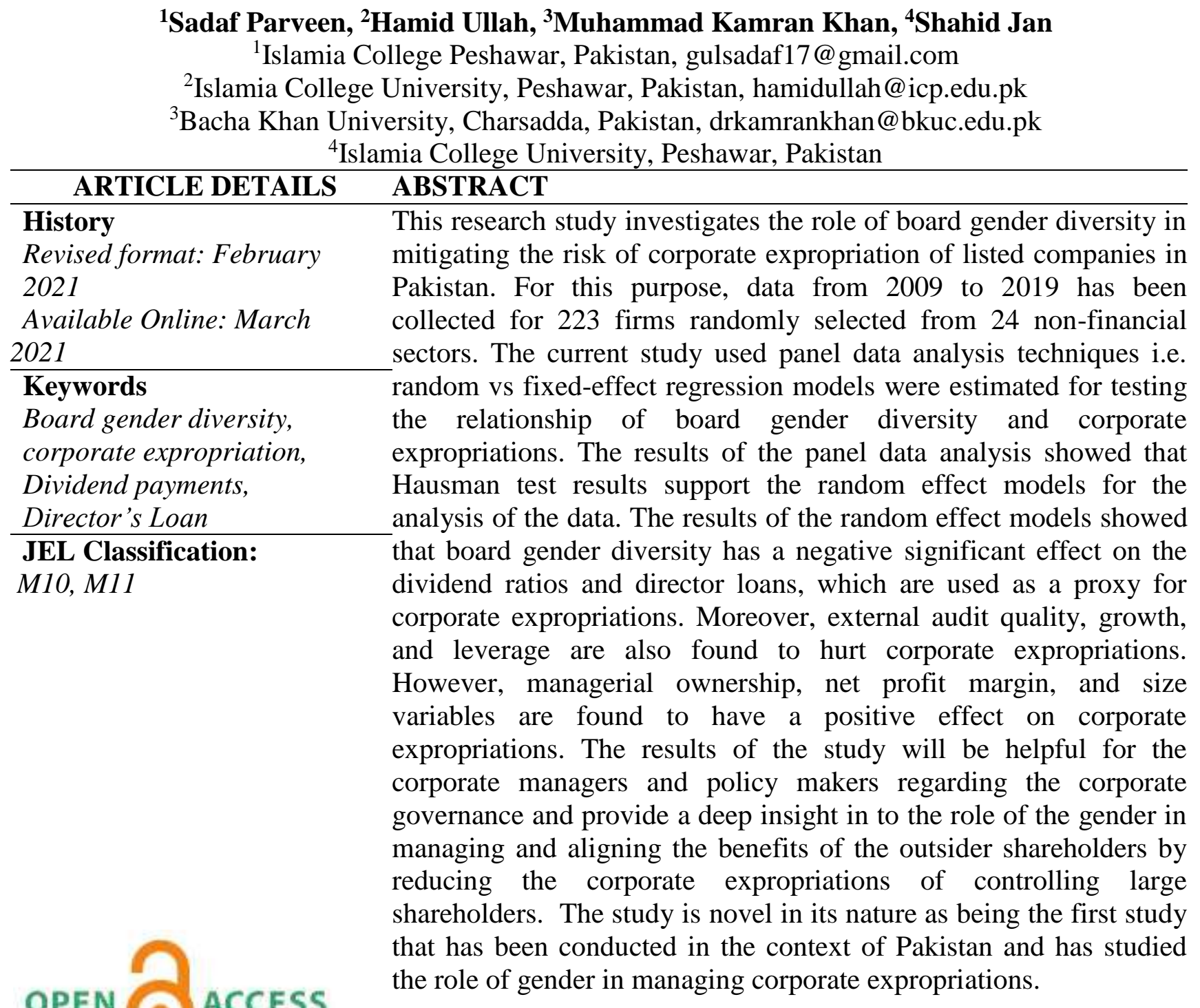

(C) 2021 The authors, under a Creative Commons Attribution-

NonCommercial 4.0

Corresponding author's email address: drkamrankhan@bkuc.edu.pk

Recommended citation: Parveen, S., Hamidullah, Khan, M. K. \& Jan, S. (2021). Board Gender

Diversity and Corporate Expropriations: Evidence from Pakistan Stock Exchange. Journal of Accounting and Finance in Emerging Economies, 7(1), 177-194

\section{Introduction}

Researchers, investors, and policymakers showed interest in assortment on boards from the past twenty years. According to Upadhyay and Zeng (2014), on the diversity of the board, women representation on board increase the board value by providing a wide range of resources, for instance, legitimacy, strategic 
advice, knowledge, and connection with outside elements of environment on which an organization depends. Due to the great significance of boards having female members at the economic level, organizations have begun more presence of women in boards. In light of this, various nations, for example, Iceland, France, and Norway have presented laws by giving authority to women presence on board, whereas some other countries, for example, Canada and UK, have joined proposals for both male and female equally in the code of corporate governance. Subsequently, females are getting progress on board, such as female had $14.8 \%$ seats of the board at Fortune 500 firms during 2013. Especially, the top country in the world is Norway whose $36.1 \%$ portion of the board consists of women members, similarly, Finland and Sweden are 26.8\% and 27\% according to GMI (2013). The role of the board, in general, has found a negative and significant impact on expropriation (See.Ullah\& Shah, 2015). However, due to the great significance of boards having female members at the economic level has paved the way for scholars to test all those components that affect the board of directors.

Policy-makers considered that the boards having gender diversity are more effective than the boards which are not gender-wise diverse and onboard representation of females is not appropriate. For the sake of these purposes, for lawmaking bodies, the gender diversity of the boards is considered a vital area of interest. According to Adams (2016) increasing the degree of board gender diversity of the board, board gender diversity guidelines are executed globally in the form of amendments of governance code, disclosure requirements, and obligatory quotas. The first country was Norway to device required quota of gender for the listed firms' boards in 2003. Othe countries of Europe that are France, Spain, Germany, Belgium, and Italy also presented provision for listed firms' boards after Norway. Regarding the gender diversity of the board, Norway is a country that took the foremost steps. Norway has $39.4 \%$ female on board of direct France and Sweden has $37.6 \%$ and $35.6 \%$ female directors on board. Korea has $2.4 \%$ of women on board as directors. According to Fondas and Sassalos (2000), past researches also recorded that independency of the board will improve with the existence of females on board (see Fondas\&Sassalos, 2000). As per Sing et al., (2008), female onboard focus on their job by staying away from politics that lead to improving the board efficiency. Hence, the female board of directors will bring a lot of advantages to the investor and will be helpful to reduce the chance of expropriation by focusing on their job effectively and efficiently on the board. Berle and Means (1932) started the first idea of agency issue. The producers gave attention to the concept of agency theory and practically used it as a huge firm. Generally, agency theory has been utilized in the field of finance, economics, political theory, human science, promoting, and organization behavior.

As the agency problem is a conflict between shareholders and its agent and it is the main cause of corporate expropriation. Corporate expropriation can be minimized through the proper application of dividend payout policies. To protect the investors from expropriation the dividends are utilized as a device to minimize the agency costs (see Adjaoud and Ben-Amar, 2010). There should be a certain connection between dividend payout and administration of corporations because organizations with better-administered will guarantee the best insurance for their investors. In this manner, investors can compel the executives to disseminate a higher dividend instead of expropriating the abundance of money for their advantages (see Mitton, T2002).

\section{Literature Review and Hypothesis Development}

This section includes both theoretical and empirical work done on the topic.

\subsection{Agency Theory}

Agency theory clarifies the connection between the shareholder (owner) and managers or directors (agents). According to Clarke (2004) investors or the shareholders of the organization, procures agents to do work on their behalf. Shareholders give the authority to their agents to take decisions and to run the organization. Undoubtedly, Daily et al (2003) concluded two components that can impact the noticeable quality of organization theory. The first component is that this theory is straightforward and it diminishes the organization into two parts that are investors and directors. The second component is that 
this theory recommends that it can lead to self-interest, directors, or agents of shareholders in associations who will perform work for their advantage and well-being.

This theory anticipates that managers or directors should work on the choices of the shareholder's intrigue. In actuality, as per Padilla (2000), it is possible that the manager or director not make good choices for the shareholder's benefit. Adam Smith firstly identified this type of issue in the eighteenth century and after that examined by Ross (1973), similarly, Jensen and Meckling (1976) firstly introduced agency theory in detail. Davis, Schoorman, and Donaldson (1997) declared without any doubt, the concept of issues rising due to division of possession and governance in agency theory.

According to Fama and Jensen (1983) to supervise the exercises of administrators and to determine clashes (for example compensation, turnover of CEO) between managers or directors and investors (shareholders) key situation is the board of directors. In a general way inside directors will not work together with outsiders for the purpose of expropriations, because they want to keep up their notoriety as checking specialists.

As per agency theory, it is contended that board adequacy can be improved due to the supervision of women directors' inboard. For example, the presence of women in the board can start the discussion on petulant problems and can Chief Executive Officer's assessment than male directors on board; in this manner, to supervise directors the board gender diversity may be a viable apparatus. Carter, Simkins, and Simpson, (2003) studied that females can be ultimate directors as females exhibit greater activism and independence as compared to non-executives.

\subsection{Corporate Expropriation}

According to Sulong and Nor (2008) expropriation is characterized as an unlawful asset expulsion, profit, and wealth particularly by major investors. For their personal benefit, they damage the interest of other small shareholders by utilizing their controlling position in the firm. Singhai (2002) reported different types of expropriations that are expropriation of profit, assets tunneling, and inappropriate ownership dilution. Related party exchange is reported by Harto, 2012. Corporate governance according to Denis and McConnel (2003) is a set of procedures and rules that influences firm decision making to increase the value of the corporation and to increase the wealth of the shareholders. Therefore, every decision and choice made by the company is planned to give advantages to all investors of the firm. Shleifer and Vishny's (1997) findings are similar to these findings. According to the "corporate governance is an act of dealing by which finance providers are guaranteed to get a profit on investment". This opinion is more explicit in clarifying the expropriation plausibility and also the role that the directors play in securing the benefits of investors. Claessens (2006) raised this with the contention that corporate governance is identified with the role of the different board of directors and shareholders. While managing business expropriation the director's job is treated as a significant component. According to Hopewell (2009), one of the problems that lead to the breakdown of Lehman Brothers (2008) is the issue of directors of the firm. He uncovered a few shortcomings that need consideration, for example, the directors' performance and the disappointment of the structure of the board as far as directors' abilities, exposure, and experience. In corporate governance one of the significant tools is the diversity of the board. The heterogeneity and successful checking of the board would upgrade boardroom practices and advance the quality of the governance in the organizations to decrease the probability of expropriation. As the greater part of the studies related to board directed towards the understanding of the impact of board structure on the performance of the company. This research is proposed to look at the connection between corporate expropriation and board diversity. Earlier studies on gender suggested that there exists a positive correlation between females on board and firm performance. Furthermore, the studies also reveal that on board the existence of females boosts the independence of the board (Feirreira, 2009). Fondas\&Sassalos, 2000, have substantial contributions to increase the quality of governance by giving a different point of view in discussion and increase the interaction of the directors of the board. According to Sing et al., (2008) the directors should focus on 
the role they play to stay away from political behavior that leads to an increase in board efficiency. Keeping in view all these studies it can be concluded that females on board would be more beneficial for the shareholder and it seems to increase the likelihood of expropriation by playing an effective role in the boardroom.

\subsubsection{Board Gender Diversity}

Up till now, scholars did not find the answer to two important questions the first question is that what plays an important role in the effectiveness of the board of directors? And the second question is what steps should be followed for the improvement of the board? For answering the said questions, Adams (2016) argued that after conducting studies from many years by academic scholars and regulators the way out of these problems lies in the independence of the board. However, the recent studies showed that the emphasis is transferred from the independence of the board to the gender diversity of the board. According to Adams (2016) boards having women, directors are more effective.

Policy-makers have the views that the boards having gender diversity are more effective than the boards which are not gender-wise diverse and onboard representation of females is not appropriate. For the sake of these purposes, for lawmaking bodies, the gender diversity of the boards is considered a vital area of interest. According to Adams (2016) increasing the degree of board gender diversity of the board, board gender diversity guidelines executed globally in the form of amendments of governance code, disclosure requirements, and obligatory quotas. The first country was Norway to device required quota of gender for the listed firm's boards in 2003. Other countries of Europe that are France, Spain, Germany, Belgium, Italy also presented provision for listed firms boards after Norway. Regarding the gender diversity of the board, Norway is a country that took the foremost steps. Norway has $39.4 \%$ female on board of direct France and Sweden has $37.6 \%$ and $35.6 \%$ of female directors on board. Korea has $2.4 \%$ of women on board as directors.

H1: There is a significant relationship between corporate expropriation and board gender diversity.

\subsubsection{Firm Size}

Hyland and Marcellino (2002) tested the effect of representation of women on board in firm size and industry. For this study data collected from the top 100 public companies of the US and the results suggested a positive association of board having women directors and organizational size. Hillman et al. (2007) also examined the representation of women directors on board with industry type and organizational size in the US and results found a significant influence of female directors on industry type and firm size. Yousaf, Belghitar, and Saeed (2016) tested different with the board having a female board of directors in the Russian, Chinese, Brazilian, and Indian boardrooms by analyzing 1002 firms data from 2005 to 2012 then compared the results with a US and UK sample. The study found between emerging economies and developed economies some similarities. In particular, the correlation of board having female directors with the firm size is positive and negatively correlated with corporate risk in developed economies and also in emerging economies.

Saeed, et al., (2019) examined different factors of organization and board having a female board of directors by taking a sample of 294 Indian firms from 2004 to 2014. The result suggested a positive relationship between board gender diversity with family ownership and firm size. Ullah and Shah (2015) investigated the relationship of firm size with related party transactions by using a sample of 160 nonfinancial firms from 2006 to 2012 and found that there is a positive and significant correlation between firm sizes and related party transactions.

$\mathrm{H} 2$ : There is a significant relationship between firm size and corporate expropriation.

\subsubsection{Audit Quality}

Ahmad and Denaley (2016) tested the representation of women on Australian corporate board on ASX500 from 2011 to 2014 by using two-limit Tobit model and this study found that board major 
determinants are index of corporate governance, debt ratio, average age of board, firm size, Global Reporting Initiative signatory, women as chair of boards, tenure of chief executive officers, Big4 auditors, and shareholder concentration. In Australia, this is the first study that used the two-limit Tobit model and examined the representation of females on board. Mustafa, Ahmad, and Chandren (2017) conducted a study on the impact of cognitive diversity (e.g education levels and interlocking directorship) and demographic diversity (e.g. age and gender) of the board of directors on client's incentives and capability to claim proxy of high audit quality by big4 auditors. Taking data of 415 firms from Turkey quoted firms from the year 2011 to 2015 and to estimate the regression using the model of random effect estimation. This study found master's degree holders boards and interlocking directorship have a positive and significant effect on clients' demand for high audit quality. This study by examining interlocking directorship with audit quality providing additional theoretical insight.

H3: There is a significant relationship between corporate expropriation and audit quality.

\subsubsection{Firm Age}

Appiadjie, Ampong, and Nsiah (2017) examined the correlation of firm age and board gender diversity in Ghana by taking 34 listed companies on Ghana's capital market from 2010 to 2014 by using regression analysis. Results concluded a significant and positive correlation of firm age and board having female directors.

H3: There is a significant relationship between firm age and corporate expropriation.

\subsubsection{Leverage}

Haris (2014) conducted a study on women directors on public company boards and examined the relationship between leverage and gender diversity in the US by taking a sample of 500 public companies boards having at least $25 \%$ women on board and companies having no woman on board for two years 2012 and 2013. The study concluded that there is an adverse correlation of board and corporate leverage and board that have at least $25 \%$ female directors on their board. Ullah and Shah (2015) tested the relationship of leverage with related party transactions by using a sample of 160 nonfinancial firms taking data from 2006 to 2012 and the result concluded that leverage is negatively and insignificantly correlated with related party's transaction. Mahajan conducted a study to test on the compensation of director and firm performance the impact of board gender diversity for listed firms of India National Stock Exchange. It also examined firm risks such as leverage and the result suggested an insignificant association of leverage and board having female directors.

H5: There is a significant relationship between corporate expropriation and firm size.

\subsubsection{Family Business}

Sarkar and Salarka (2015) conducted a study on women on board and performance of family firms with a case study from India by using a data-set of 10218 firms of ten-year observation from 2005 to 2014. The result found that on family firms there is a positive impact on gender diversity. Abdullah, Ismail, and Nachum (2015) conducted a study by utilizing the Malaysian firm's sample and the result suggested a significant and positive association of board gender diversity with state-ownership and family ownership.

H6: There is a significant relationship between the family business and corporate expropriation.

\subsubsection{Institutional Ownership}

Rodriguez and Lawrence conducted a study on institutional investors that avoid women. The study tested on institutional ownership the influence of board having female directors. The study found that on average institutional investors hold 8 to $9 \%$ less equity infirm with $20 \%$ female representation on the board as compared to firms with no diversity. So this study concluded a large inverse relationship of institutional ownership and board having female members. A large number of studies suggested that institutional investors perform a monitoring job in a firm. The increasing number of institutional investors will provide more information. Saito (2017) conducted a study on board gender diversity and organizational diversity in Japan. Onboard the ratio of women directors in Japan was only 3 percent in 
2016, which is one of the lowest among the OECD countries. The study examined the data of listed firms in Japan and explored in terms of board gender diversity the influence of institutional change on organizational diversity. It found that to mitigate institutional pressure as incentive firms take institutional change. While new policies and increasing foreign investors encourage gender diversity and independence on boards.

H7: There is a significant relationship between corporate expropriation and institutional ownership.

\subsubsection{Firm Growth}

Durnev and Guriev (2011) conducted a study that expropriation risk reduces firm growth and decreases capital allocation efficiency.The model of this study declared that by reducing transparency, corporations minimize expropriation risk in countries with insecure property rights. This channel used data from 84 companies and the results found that reduced transparency has adversely influence corporate growth and efficient allocation of capital. Ullah and Shah (2015) study found an insignificant and negative correlation of firm growth with related party transactions.

H8: There is a significant relationship between corporate expropriation and firm growth.

\subsubsection{Managerial Ownership}

Ullah and Shah (2015) conducted a study on related party transactions and corporate governance mechanisms of Pakistani firms. Used a sample of 160 non-financial firms from 2006 to 2012. The study shows that incorporate governance the main role is of institutional ownership. Managerial ownership is an agent that expropriates minor shareholder wealth through related party transactions. However; audit quality plays the role of an external governance agent and can reduce the conflict between minor and major shareholders. The result of this study found a significant and positive relationship of managerial ownership with related party transactions. As Pakistani is a developing economy and characterized by ownership concentration, most firms are dominated by families and their major shareholders are family members in many family firms. Thus the higher managerial ownership the higher will be the expropriation because they can divert the funds and assets to other family firms and minor shareholders will suffer.

H9: There is a significant relationship between corporate expropriation and managerial ownership.

\subsubsection{Foreign Ownership}

The nationality of the board members is another element of board gender diversity. As per Oxelheim and Randoy (2002), the existence of foreign board members brought improvement in the performance of the firm by monitoring and controlling the powers of management. These functions of monitoring and controlling help reduce expropriations. Choi et al., (2012) explored the direct and indirect influence of foreign board members on board by using data from 2007 to 2014 in Korea. The study found that foreign shareholders monitor the management independently and this independency has a positive influence on the performance of the firm and foreign members of the board have been considered an important element of corporate governance. Hamzah and Zulkafli (2014) conducted a study to examine the association between corporate expropriation and board gender diversity of public listed companies in Malaysia. This study considered that foreign members as directors of the board, female members on board, and also tenure of the board are important tools for reducing expropriation by providing monitoring at a high level and it will be helpful to improve the quality of governance infirm and enhance the discussion of board. The study found a positive and significant relationship between board gender diversity and corporate expropriation and indicated that the presence of foreign investors on board helps reduce corporate expropriation.

H10: There is a significant relationship between corporate expropriation and foreign ownership.

\section{Research Methodology}

\subsection{Population}

The population of the study is non-financial firms listed in the Pakistan Stock exchange. There are a total of 35 sectors listed in the Pakistan Stock Exchange in which 6 are financial sectors and 29 are non- 
financial sectors.

\subsection{Sample Size}

A representative sample of about 223 firms randomly selected from the firms listed in the Pakistan Stock Exchange from 2009 to 2019. Furthermore, the sample will be subject to the availability of data onboard diversity in firms and other variables of interest.

\subsection{Model Specification}

The current study has used the research model specification of Hazah and Zulkafli(2014) with minor modification by including corporate expropriation as dependent variable while board gender diversity is an independent variable and also included audit equity, managerial ownership, institutional ownership, firm growth, net profit margin, leverage and firm size variable.

\section{Expropriation $_{i t}=\alpha+\beta$ BGD $_{i t}+\beta$ Eaq $_{i t}+\beta$ Forit $+\beta$ Msoit $^{+} \beta$ Instit $+\beta$ Growth $_{i t}+\beta \mathrm{Npm}_{\text {it }}+$ $\beta L e v i t+\beta S i z e i t+$ ei}

Where, BGD board gender diversity, Eaq audit quality, For foreign ownership, Mso managerial ownership, Inst institutional ownership, Growth firm growth, Npm net profit margin, Lev leverage, Size firm size

\subsection{Variables}

\subsubsection{Dependent Variables}

\subsubsection{Corporate Expropriation}

For this study two proxies are used for corporate expropriation. The first one is dividend payout that is the total dividend paid to common and preferred shareholders. For this purpose, data is extracted from the balance sheets of companies. Different previous studies such as Mancinelli and Ozkan (2006), Pindado and Torre (2006), and Cronqvist and Fahlenbrach (2009) have used dividend payout for the measurement of dividend policy. According to Hamzah and Zulkafli (2014), dividend payout is computed as a dividend paid to sales used as a proxy for expropriation and the second one is related party loan dividends by total assets is used as a proxy for expropriation.

\subsubsection{Independent Variables}

\subsubsection{Board Gender Diversity}

Board gender diversity is computed by using the total female members on the board. Buniamin et al., (2012) has also used the same measure for their study. Rodriguez and Lawrence conducted a study on institutional investors that avoid women and compute board gender diversity by using a total female member on the board. Adams (2016) computed board gender diversity by taking the total number of female members out of total board members. Abdul Manaf et al., (2016), conducted a study in Malaysia and also used board gender diversity by measuring the number of female board members on the board. Farrell (2004) conducted a study on the female effect on the corporate board and used board gender diversity as a variable by computing the number of female members aboard.

\subsubsection{Audit Quality}

Each refers to audit quality. The total fee paid to the auditors is used for its calculation. Ullah and Shah (2015) also conducted a study and used total fees paid to the auditors for calculating audit quality. Gao and King (2008) argued that those firms whose performance is high pay high audit fees to auditors for a better analysis of financial records. Mustafa, et al., (2017) examined the demand of clients for high audit quality, and for this purpose, they used audit quality as available by measuring the total fee paid to the auditor for his study. 


\subsubsection{Foreign Ownership}

Foreign ownership is the total number of foreigners on board and it is computed as the portion of shares held by foreign investors out of total ownership (Hamzah \& Zulkafli, 2014). Saito (2017) conducted a study in Japan and used foreign ownership as a variable by measuring ownership percentage of foreign investors. Denis and Huizinga (2004) used a foreign variable for their study by measuring that foreign ownership is the ratio of foreign ownership in total equity. Viet conducted a study on foreign ownership and performance of listed firms and measure foreign ownership by taking the percentage of foreign ownership.

\subsubsection{Managerial Ownership}

Mso refers to managerial ownership. It is calculated as a percentage of managerial ownership out of total ownership (Saeed, et al., 2018). Ullah and Shah (2015) conducted a study and calculate the managerial ownership out of total ownership. Benkraiem, et al., (2017) conducted a study and used managerial ownership as a variable by measuring managerial ownership out of total ownership and found that 77.6 percent are managerial ownership ratio.

\subsubsection{Institutional Ownership}

Inst refers to institutional ownership and computed as a percentage of institutional ownership out of total ownership (Saeed, et al., 2018). The family business is represented by 1 if it belongs to the family otherwise (Saeed, et al., 2018). Rodriguez and Lawrence conducted a study and used the total percentage of institutional investors out of total shares. Ullah and Shah (2015) conducted a study on related party transactions and corporate governance mechanisms of Pakistani firms and used institutional ownership variables by computing the percentage of institutional ownership out of total ownership. Farrell (2004) conducted a study that used institutional ownership as a variable by computing the percentage of shares held by institutional investors.

\subsubsection{Growth}

Growth refers to firm growth. It is calculated as the changes that occurred in the fixed assets of the firm. Ullah and Shah (2015) conducted a study and used firm growth as a control variable by calculating changes that occurred in fixed assets of the firm. Durnev and Guriev (2011) conducted a study on expropriation risk and firm growth and measured the firm growth variable by taking the annual growth in real sales.

\subsubsection{Net Profit Margin}

The term Npm in the econometric model refers to the net profit margin. Appiadjei and Ampong (2017) conducted a study on board gender diversity by using data of 34 companies listed on the capital market in Ghana. For this study net profit margin has been as a variable by taking the data of net profit of the firm's sale after the deduction of tax and depreciation. A high net profit margin is better for a firm (Appiadjei \& Ampong, 2017).

\subsubsection{Leverage}

Lev term in the econometric model refers to leverage and it is computed as debts to equity (Saeed, et al., 2018). Leverage can be computed in different ways. Abdul Manaf et al., (2016), conducted a study in Malaysia and used leverage variable as a control variable by computing as total liabilities to total assets. Benkraiem et al., (2017), carried out a research study and used leverage as a variable by computing it as total debt divided by total assets. Haris (2014) carried out a study by taking data of US companies and use leverage as a variable by computing total debt divided by total assets. Upadhyay (2014) used leverage as total debt to total equity.

\subsubsection{Size}

Size refers to firm size. To control the influence of size effect, firm size is used. Because it is expected that dividend policy is affected by firm size. Large firms have greater opportunities for growth and also 
of great financing (Sulong, 2008). Size is computed by a log of total assets (Hamzah \& Zulkafli. 2014). Ullah and Shah (2015) conducted a study and used firm size as a variable by computing a log of total assets. Abdul Manaf et al., (2016), conducted a study in Malaysia and used firm size variables by computing by a log of total assets. Sarkar and Selarka (2015) conducted a study in India and firm size as a variable by measuring the log of total assets.

\section{Results and Discussion}

This section of the study includes results and discussion on the results in light of the previous studies and theories underlying the current study.

\subsection{Descriptive Statistics}

Descriptive statistics result shows that on average the dividend to sale on non-financial firms is 0.024 which may increase up to 0.247 and the mean value of dividend to earning is 0.005 which could increase up to 0.141 . The ratio of the director's loan of non-financial firms is 0.030 which may increase up to 0.219. The gender diversity ratio is 0.374 which can increase to 1 . The ratio of external audit quality is 1.906 which may increase up to 7.6. The ratio of managerial ownership is 0.058 and the maximum value is 0.812 . The mean value of institutional ownership is 0.022 which can go up to 0.244 and the minimum value of growth ratio of non-financial firms is -.02 which may increase up to 0.397 while the mean value is also .397. The minimum value of net profit to sale is -.010 which may increase to 0.694 while the average value is .079 and the leverage ratio that is debt to equity is 0.025 and the maximum value is 0.243 . The size ratio of non-financial firs is 5.744 which may increase to 8.797 .

Table 4.1 Descriptive Statistics

\begin{tabular}{llllll}
\hline Variable & Obs & Mean & Std.Dev. & Min & Max \\
\hline Divsal & 2014 & .024 & .052 & 0 & .247 \\
Diverning & 2014 & .005 & .02 & 0 & .141 \\
dir_loan & 1242 & .030 & .128 & 0 & .219 \\
bgd1 & 2014 & .374 & .484 & 0 & 1 \\
Eaq & 2012 & 1.906 & 2.863 & 0 & 7.6 \\
For & 2014 & .005 & .021 & 0 & .25 \\
Mso & 2014 & .058 & .15 & 0 & .812 \\
Inst & 2014 & .022 & .048 & 0 & .244 \\
Growth & 2014 & .039 & .086 & -.02 & .397 \\
Npm & 2014 & .079 & .156 & -.01 & .694 \\
Lev & 2014 & .025 & .027 & 0 & .243 \\
Size & 2014 & 5.744 & 1.413 & 0 & 8.797 \\
\hline
\end{tabular}

\subsection{Matrix of Correlations}

The matrix of correlations shows the correlation between the dependent and independent variables. The dependent variable is the expropriation and explanatory variable is board gender diversity while control variables are external audit quality, dividend to sale, dividend to earning, director's loan, foreign ownership, managerial ownership, institutional ownership, growth, net profit margin, leverage, and size. The results show a negative association of corporate expropriation with board gender diversity, and also a negative association with other control variables such as dividend to earning, director's loan, external 
audit quality, growth, and leverage. The results also show that corporate expropriation has a positive association with a dividend to sale, foreign ownership, managerial ownership, institutional ownership, net profit margin, and size.

Table 4.2 Matrix of correlations

\begin{tabular}{|c|c|c|c|c|c|c|c|c|c|c|c|c|c|}
\hline Variables & (1) & (2) & (3) & (4) & (5) & (6) & (7) & (8) & (9) & (10) & (11) & (12) & (13) \\
\hline (1) divsal & 1.000 & & & & & & & & & & & & \\
\hline $\begin{array}{l}\text { (2) } \\
\text { diverning }\end{array}$ & -0.011 & 1.000 & & & & & & & & & & & \\
\hline $\begin{array}{l}\text { (3) } \\
\text { dir_loan }\end{array}$ & -0.062 & 0.024 & 1.000 & & & & & & & & & & \\
\hline (4) bgd1 & -0.073 & -0.014 & -0.021 & 1.000 & & & & & & & & & \\
\hline (5) eaq & -0.057 & -0.122 & -0.045 & 0.146 & 1.000 & & & & & & & & \\
\hline (6) for & 0.100 & 0.051 & 0.033 & -0.249 & 0.227 & 1.000 & & & & & & & \\
\hline (7) mso & 0.153 & 0.028 & 0.053 & 0.094 & 0.042 & -0.098 & 1.000 & & & & & & \\
\hline (8) inst & 0.062 & 0.073 & 0.095 & 0.128 & 0.345 & -0.041 & -0.061 & 1.000 & & & & & \\
\hline (9) growth & -0.125 & -0.027 & -0.046 & 0.124 & -0.132 & -0.148 & -0.063 & 0.043 & 1.000 & & & & \\
\hline (10) npm & 0.513 & 0.069 & 0.001 & -0.143 & 0.062 & 0.217 & -0.157 & -0.021 & -0.042 & 1.000 & & & \\
\hline (1) lev & -0.228 & -0.122 & -0.116 & 0.040 & 0.087 & -0.080 & 0.068 & -0.062 & 0.072 & 0.164 & 1.000 & & \\
\hline (12) size & 0.345 & 0.134 & 0.065 & -0.049 & 0.096 & -0.019 & -0.110 & -0.003 & 0.149 & 0.375 & 0.604 & 1.000 & \\
\hline
\end{tabular}

\subsection{Regression Results}

The regression result is the test of a regression model where random and fixed regression models were used. The Hausman test results suggest that the random effect model is appropriate. The results show that the coefficient of board gender diversity has a coefficient of -0.008 which is significant at a $5 \%$ level of significance and thus accepts the alternate hypothesis of the significant relationship of board gender diversity and corporate expropriations. The negative sign shows that firms with more females on board will have less expropriation, moreover, these results support the notion that the presence of females in the corporate board could pay an important role in reducing conflicts between majority and minority shareholders and could help in reducing the corporate expropriations. The external audit quality has a coefficient of -0.011 which is negative and significant at a $1 \%$ level of significance. Ullah and Shah (2015) also verified the negative and significant association of audit quality with related party transactions. Thus, accept the alternate hypothesis of the significant relationship of corporate expropriation and audit quality. The value of foreign ownership is -0.018 which shows the negative and does not lie in the significance area. So here the $\mathrm{H} 1$ rejected that there is a significant relationship between corporate expropriation and foreign ownership and null hypothesis Ho accepted that there is an insignificant relationship between corporate expropriation and foreign ownership. The managerial ownership has a coefficient of 0.006 which shows a positive and significant at a $5 \%$ level of significance. Results are also supported by the study of Ullah and Shah (2015). Here accepted the hypothesis of a significant relationship between corporate expropriation and managerial ownership and the null hypothesis rejected that is an insignificant relationship between corporate expropriation and managerial ownership. The value of institutional ownership is 0.034 which is a positive and insignificant relationship with corporate expropriation. The alternate hypothesis accepted that there is an insignificant relationship between corporate expropriation and institutional ownership. The growth value coefficient is -0.026 which shows negative and significant at the $10 \%$ level. Thus, accept the hypothesis of the significant relationship of firm growth and corporate expropriation and the null hypothesis rejected that there is an insignificant relationship between corporate expropriation and growth rate. The value of the 
net profit margin is 0.033 which shows a positive and significant at $5 \%$ level of significance. $\mathrm{H} 1$ will accept the hypothesis of a significant relationship between corporate expropriation and net profit margin. Leverage has a coefficient of -0.062 which is a negative and insignificant relationship with corporate expropriation. So here rejected the hypothesis of a significant relationship between leverage and corporate expropriation. The coefficient of size is 0.005 which represents a positive and significant at a $1 \%$ level of significance. The $\mathrm{H} 1$ accepted that there is a significant relationship between corporate expropriation and size. The results of Hyland and Marcellino (2002) study also support this finding.

4.3 Regression Results

\begin{tabular}{|c|c|c|c|c|c|c|}
\hline & $\begin{array}{c}\text { (RE) } \\
\text { Divsal }\end{array}$ & $\begin{array}{c}(\mathrm{FE}) \\
\text { Divsal }\end{array}$ & $\begin{array}{c}(\mathrm{RE}) \\
\text { Diverning }\end{array}$ & $\begin{array}{c}(\mathrm{FE}) \\
\text { diverning }\end{array}$ & $\begin{array}{c}(\mathrm{RE}) \\
\text { dir_loan }\end{array}$ & $\begin{array}{c}(\mathrm{FE}) \\
\text { dir_loan }\end{array}$ \\
\hline BGD & $\begin{array}{l}-0.008^{* *} \\
(0.004)\end{array}$ & $\begin{array}{l}-0.011 * * \\
(0.005)\end{array}$ & $\begin{array}{l}-0.005 * * \\
(0.002)\end{array}$ & $\begin{array}{l}-0.005^{*} \\
(0.003)\end{array}$ & $\begin{array}{l}-0.007^{* *} \\
(0.003)\end{array}$ & $\begin{array}{l}-0.064 * * \\
(0.031)\end{array}$ \\
\hline Eaq & $\begin{array}{l}-0.011 * * * \\
(0.001)\end{array}$ & $\begin{array}{l}-0.012 * * * \\
(0.001)\end{array}$ & $\begin{array}{l}-0.001 * * \\
(0.000)\end{array}$ & $\begin{array}{l}-0.001 * * \\
(0.000)\end{array}$ & $\begin{array}{l}-0.009 * * \\
(0.008)\end{array}$ & $\begin{array}{l}-0.007 * * \\
(0.003)\end{array}$ \\
\hline For & $\begin{array}{l}-0.018 \\
(0.062)\end{array}$ & $\begin{array}{l}-0.026 \\
(0.078)\end{array}$ & $\begin{array}{l}-0.021 \\
(0.031)\end{array}$ & $\begin{array}{l}-0.028 \\
(0.042)\end{array}$ & $\begin{array}{l}-0.474 \\
(0.295)\end{array}$ & $\begin{array}{l}-0.627 \\
(0.423)\end{array}$ \\
\hline Mso & $\begin{array}{l}0.006 * * \\
(0.003)\end{array}$ & $\begin{array}{l}0.006 * * \\
(0.003)\end{array}$ & $\begin{array}{l}0.007 * * \\
(0.003)\end{array}$ & $\begin{array}{l}0.008 * * \\
(0.003)\end{array}$ & $\begin{array}{l}0.053 * * * \\
(0.015)\end{array}$ & $\begin{array}{l}0.072 * * \\
(0.029)\end{array}$ \\
\hline Inst & $\begin{array}{l}0.034 \\
(0.037)\end{array}$ & $\begin{array}{l}0.033 \\
(0.047)\end{array}$ & $\begin{array}{l}0.019 \\
(0.015)\end{array}$ & $\begin{array}{l}0.028 \\
(0.019)\end{array}$ & $\begin{array}{l}-0.080 * * * \\
(0.023)\end{array}$ & $\begin{array}{l}-0.241 * * \\
(0.119)\end{array}$ \\
\hline Growth & $\begin{array}{l}-0.026^{*} \\
(0.014)\end{array}$ & $\begin{array}{l}-0.027^{*} \\
(0.014)\end{array}$ & $\begin{array}{l}-0.011 * * * \\
(0.004)\end{array}$ & $\begin{array}{l}-0.010 * * \\
(0.004)\end{array}$ & $\begin{array}{l}-0.005 \\
(0.057)\end{array}$ & $\begin{array}{l}-0.012 \\
(0.057)\end{array}$ \\
\hline $\mathrm{Npm}$ & $\begin{array}{l}0.033 * * \\
(0.013)\end{array}$ & $\begin{array}{l}0.037 * * * \\
(0.013)\end{array}$ & $\begin{array}{l}0.010 * * \\
(0.004)\end{array}$ & $\begin{array}{l}0.013 * * * \\
(0.004)\end{array}$ & $\begin{array}{l}0.090 * * \\
(0.037)\end{array}$ & $\begin{array}{l}0.136 * * \\
(0.065)\end{array}$ \\
\hline Lev & $\begin{array}{l}-0.062 \\
(0.067)\end{array}$ & $\begin{array}{l}-0.084 \\
(0.072)\end{array}$ & $\begin{array}{l}-0.042 * \\
(0.023)\end{array}$ & $\begin{array}{l}-0.050 * \\
(0.027)\end{array}$ & $\begin{array}{l}0.316^{* * *} \\
(0.126)\end{array}$ & $\begin{array}{l}0.382 * * \\
(0.150)\end{array}$ \\
\hline Size & $\begin{array}{l}0.005^{* * * *} \\
(0.001)\end{array}$ & $\begin{array}{l}0.005 * * * \\
(0.001)\end{array}$ & $\begin{array}{l}0.001 * * \\
(0.000)\end{array}$ & $\begin{array}{l}0.001 * * \\
(0.000)\end{array}$ & $\begin{array}{l}0.006 * * * \\
(0.002)\end{array}$ & $\begin{array}{l}0.006 * * * \\
(0.002)\end{array}$ \\
\hline _cons & $\begin{array}{l}-0.006 \\
(0.004)\end{array}$ & $\begin{array}{l}-0.010 * * \\
(0.005)\end{array}$ & $\begin{array}{l}0.002 \\
(0.002)\end{array}$ & $\begin{array}{l}0.000 \\
(0.002)\end{array}$ & $\begin{array}{l}-0.045^{*} \\
(0.023)\end{array}$ & $\begin{array}{l}-0.044^{*} \\
(0.022)\end{array}$ \\
\hline $\begin{array}{l}\text { Obs. } \\
\text { R-squared }\end{array}$ & $\begin{array}{l}2012 \\
0.137\end{array}$ & $\begin{array}{l}2012 \\
0.147\end{array}$ & $\begin{array}{l}2012 \\
0.134\end{array}$ & $\begin{array}{l}2012 \\
0.137\end{array}$ & $\begin{array}{l}1242 \\
0.102\end{array}$ & $\begin{array}{l}1242 \\
0.102\end{array}$ \\
\hline Hausman Test & \multicolumn{2}{|c|}{$12.15(0.2052)$} & \multicolumn{2}{|c|}{$10.12(0.2311)$} & \multicolumn{2}{|c|}{$16.23(0.1623)$} \\
\hline
\end{tabular}

Standard errors are in parenthesis $* * * p<0.01, * * p<0.05, * p<0.1$

\subsection{Regression Results of Interaction Models for Dividend to earnings (Diverning)}

Now to test that the effect of board gender diversity on corporate expropriation varies with the level of managerial ownership, foreign ownership, institutional ownership, leverage, size, and net profit margin, the study has estimated the interaction effect of each of these variables on the various measures of corporate expropriation. Table 4.4 showed the results of the interaction models where the dependent variable of the study is a dividend to earnings ratio used as a proxy for expropriation. The explanatory variables include board gender diversity and its interaction with managerial ownership (bgd_mso), institutional ownership (bgd_inst), foreign ownership (bgd_for), net profit margin (bgd_npm), leverage (bgd_Lev) and size of firm (bgd_size) respectively. Moreover, the study also kept the main variables used in the baseline model such as managerial ownership, foreign ownership, institutional ownership, and external audit quality, and firm-level variables such as leverage, net profit margin, growth, and size. The estimated results of the random effect models showed that in all models' board gender diversity has a negative and significant effect on the dividend to earnings ratio. These results are in line with the baseline regression model as reported in table 4.3. The interaction of the board gender diversity with the managerial ownership has a negative and significant coefficient with the dividend to earnings ratio. However, managerial ownership alone has a significant positive effect on the dividend to earnings ratio. Thus, these results suggested that in the presence of females in the corporate board mitigate the expropriating behavior of the dominant managers in firms. Thus, diversity in the corporate board could protect the interest of the minority shareholders by reducing the probability of corporate expropriations. These results support the main results of the study that is gender diversity minimizes corporate 
expropriations.

4.4 Regression Results of Interaction Models for Dividend to earnings (Diverning)

\begin{tabular}{|c|c|c|c|c|c|c|}
\hline & $\begin{array}{c}\text { (MSO) } \\
\text { Diverning } \\
\end{array}$ & $\begin{array}{c}\text { (INST) } \\
\text { Diverning } \\
\end{array}$ & $\begin{array}{c}\text { (FOR) } \\
\text { Diverning } \\
\end{array}$ & $\begin{array}{c}\text { (NPM) } \\
\text { Diverning } \\
\end{array}$ & $\begin{array}{c}\text { (LEV) } \\
\text { Diverning } \\
\end{array}$ & $\begin{array}{c}\text { (SIZE) } \\
\text { Diverning } \\
\end{array}$ \\
\hline BGD & $\begin{array}{l}-0.005 * * \\
(0.002)\end{array}$ & $\begin{array}{l}-0.005^{*} \\
(0.003)\end{array}$ & $\begin{array}{l}-0.005 * * \\
(0.002)\end{array}$ & $\begin{array}{l}-0.005^{*} \\
(0.003)\end{array}$ & $\begin{array}{l}-0.005 * * \\
(0.002)\end{array}$ & $\begin{array}{l}-0.005 * \\
(0.003)\end{array}$ \\
\hline bgd_mso & $\begin{array}{l}-0.033 * * \\
(0.015)\end{array}$ & & & & & \\
\hline bgd_inst & & $\begin{array}{l}-0.064 \\
(0.048)\end{array}$ & & & & \\
\hline bgd_for & & & $\begin{array}{l}0.240 * * \\
(0.109)\end{array}$ & & & \\
\hline bgd_npm & & & & $\begin{array}{l}-0.045 * * * * \\
(0.010)\end{array}$ & & \\
\hline bgd_lev & & & & & $\begin{array}{l}-0.114 \\
(0.078)\end{array}$ & \\
\hline bgd_size & & & & & & $\begin{array}{l}-0.021 * * * \\
(0.001)\end{array}$ \\
\hline $\mathrm{Eaq}$ & $\begin{array}{l}-0.001 * * \\
(0.000)\end{array}$ & $\begin{array}{l}-0.001 * * \\
(0.000)\end{array}$ & $\begin{array}{l}-0.001 * * \\
(0.000)\end{array}$ & $\begin{array}{l}-0.001 * * \\
(0.000)\end{array}$ & $\begin{array}{l}-0.001^{* *} \\
(0.000)\end{array}$ & $\begin{array}{l}-0.001 * * \\
(0.000)\end{array}$ \\
\hline For & $\begin{array}{l}-0.021 \\
(0.031)\end{array}$ & $\begin{array}{l}-0.028 \\
(0.042)\end{array}$ & $\begin{array}{l}-0.021 \\
(0.031)\end{array}$ & $\begin{array}{l}-0.028 \\
(0.042)\end{array}$ & $\begin{array}{l}-0.021 \\
(0.031)\end{array}$ & $\begin{array}{l}-0.028 \\
(0.042)\end{array}$ \\
\hline Mso & $\begin{array}{l}0.007 * * \\
(0.003)\end{array}$ & $\begin{array}{l}0.008 * * \\
(0.003)\end{array}$ & $\begin{array}{l}0.007 * * \\
(0.003)\end{array}$ & $\begin{array}{l}0.008 * * \\
(0.003)\end{array}$ & $\begin{array}{l}0.007 * * \\
(0.003)\end{array}$ & $\begin{array}{l}0.008 * * \\
(0.003)\end{array}$ \\
\hline Inst & $\begin{array}{l}0.019 \\
(0.015)\end{array}$ & $\begin{array}{l}0.028 \\
(0.019)\end{array}$ & $\begin{array}{l}0.019 \\
(0.015)\end{array}$ & $\begin{array}{l}0.028 \\
(0.019)\end{array}$ & $\begin{array}{l}0.019 \\
(0.015)\end{array}$ & $\begin{array}{l}0.028 \\
(0.019)\end{array}$ \\
\hline Growth & $\begin{array}{l}-0.011 * * * \\
(0.004)\end{array}$ & $\begin{array}{l}-0.010^{* * *} \\
(0.004)\end{array}$ & $\begin{array}{l}-0.011 * * * \\
(0.004)\end{array}$ & $\begin{array}{l}-0.010 * * \\
(0.004)\end{array}$ & $\begin{array}{l}-0.011 * * * \\
(0.004)\end{array}$ & $\begin{array}{l}-0.010 * * \\
(0.004)\end{array}$ \\
\hline $\mathrm{Npm}$ & $\begin{array}{l}0.010 * * \\
(0.004)\end{array}$ & $\begin{array}{l}0.013 * * * \\
(0.004)\end{array}$ & $\begin{array}{l}0.010 * * \\
(0.004)\end{array}$ & $\begin{array}{l}0.013 * * * \\
(0.004)\end{array}$ & $\begin{array}{l}0.010^{* * *} \\
(0.004)\end{array}$ & $\begin{array}{l}0.013 * * * \\
(0.004)\end{array}$ \\
\hline Lev & $\begin{array}{l}-0.042 * \\
(0.023)\end{array}$ & $\begin{array}{l}-0.050 * \\
(0.027)\end{array}$ & $\begin{array}{l}-0.042 * \\
(0.023)\end{array}$ & $\begin{array}{l}-0.050^{*} \\
(0.027)\end{array}$ & $\begin{array}{l}-0.042 * \\
(0.023)\end{array}$ & $\begin{array}{l}-0.050 * \\
(0.027)\end{array}$ \\
\hline Size & $\begin{array}{l}0.001 * * \\
(0.000)\end{array}$ & $\begin{array}{l}0.001 * * \\
(0.000)\end{array}$ & $\begin{array}{l}0.001 * * \\
(0.000)\end{array}$ & $\begin{array}{l}0.001 * * \\
(0.000)\end{array}$ & $\begin{array}{l}0.001 * * \\
(0.000)\end{array}$ & $\begin{array}{l}0.001 * * \\
(0.000)\end{array}$ \\
\hline _cons & $\begin{array}{l}0.002 \\
(0.002)\end{array}$ & $\begin{array}{l}0.000 \\
(0.002)\end{array}$ & $\begin{array}{l}0.002 \\
(0.002)\end{array}$ & $\begin{array}{l}0.000 \\
(0.002)\end{array}$ & $\begin{array}{l}0.002 \\
(0.002)\end{array}$ & $\begin{array}{l}0.000 \\
(0.002)\end{array}$ \\
\hline Obs. & 2012 & 2012 & 2012 & 2012 & 2012 & 2012 \\
\hline R-squared & 0.138 & 0.137 & 0.139 & 0.138 & 0.139 & 0.137 \\
\hline Hausman Test & $10.12(0.2311)$ & $10.12(0.2311)$ & $10.12(0.2311)$ & $10.12(0.2311)$ & $10.12(0.2311)$ & $10.12(0.2311)$ \\
\hline
\end{tabular}

Standard errors are in parenthesis

$* * * p<0.01, * * p<0.05, * p<0.1$

\subsection{Regression Results of Interaction Models for Dividend to earnings (Dir_Loan)}

Table 4.5 showed the results of the interaction models where the dependent variable of the study is a dividend to earnings ratio used as a proxy for expropriation. The explanatory variables include board gender diversity and its interaction with managerial ownership (bgd_mso), institutional ownership (bgd_inst), foreign ownership (bgd_for), net profit margin (bgd_npm), leverage (bgd_Lev) and size of firm (bgd_size) respectively. Moreover, the study also kept the main variables used in the baseline model such as managerial ownership, foreign ownership, institutional ownership, and external audit quality, and firm-level variables such as leverage, net profit margin, growth, and size. The estimated results of the random effect models showed that with board gender diversity the managerial ownership, institutional ownership, and size has a negative and significant effect on the dividend to earnings ratio (dir-loan). These results are in line with the baseline regression model as reported in table 4.3. The interaction of the board gender diversity with the managerial ownership has a negative and significant coefficient with the dividend to earnings ratio. However, managerial ownership alone has a significant positive effect on the dividend to earnings ratio. Thus, these results suggested that in the presence of females in the corporate board mitigate the expropriating behavior of the dominant managers in firms. 
Thus, diversity in the corporate board could protect the interest of the minority shareholders by reducing the probability of corporate expropriations. These results support the main results of the study that is gender diversity minimizes corporate expropriations.

4.5 Regression Results of Interaction Models for Dividend to earnings (Dir_Loan)

\begin{tabular}{|c|c|c|c|c|c|c|}
\hline & $\begin{array}{c}\text { (MSO) } \\
\text { Dir_loan }\end{array}$ & $\begin{array}{l}\text { (INST) } \\
\text { Dir_loan }\end{array}$ & $\begin{array}{c}\text { (FOR) } \\
\text { Dir_loan }\end{array}$ & $\begin{array}{c}\text { (NPM) } \\
\text { Dir_loan }\end{array}$ & $\begin{array}{c}\text { (LEV) } \\
\text { Dir_loan }\end{array}$ & $\begin{array}{c}\text { (SIZE) } \\
\text { Dir_loan }\end{array}$ \\
\hline BGD & $\begin{array}{l}-0.007 * * \\
(0.003)\end{array}$ & $\begin{array}{l}-0.064 * * \\
(0.031)\end{array}$ & $\begin{array}{l}-0.007 * * \\
(0.003)\end{array}$ & $\begin{array}{l}-0.007 * * \\
(0.003)\end{array}$ & $\begin{array}{l}-0.007 * * \\
(0.003)\end{array}$ & $\begin{array}{l}-0.064 * * \\
(0.031)\end{array}$ \\
\hline bgd_mso & $\begin{array}{l}-0.007^{* *} \\
(0.003)\end{array}$ & & & & & \\
\hline bgd_inst & & $\begin{array}{c}-0.221 * * \\
(0.010)\end{array}$ & & & & \\
\hline bgd_for & & & $\begin{array}{l}-0.019 \\
(0.040)\end{array}$ & & & \\
\hline bgd_npm & & & & $\begin{array}{l}-0.001 \\
(0.005)\end{array}$ & & \\
\hline bgd_lev & & & & & $\begin{array}{l}-0.008 \\
(0.029)\end{array}$ & \\
\hline bgd_size & & & & & & $\begin{array}{l}-0.001 * * \\
(0.000)\end{array}$ \\
\hline Eaq & $\begin{array}{l}-0.009 * * \\
(0.008)\end{array}$ & $\begin{array}{l}-0.007 * * \\
(0.003)\end{array}$ & $\begin{array}{l}-0.009 * * \\
(0.008)\end{array}$ & $\begin{array}{l}-0.009 * * \\
(0.008)\end{array}$ & $\begin{array}{l}-0.009 * * \\
(0.008)\end{array}$ & $\begin{array}{l}-0.007 * * \\
(0.003)\end{array}$ \\
\hline For & $\begin{array}{l}-0.474 \\
(0.295)\end{array}$ & $\begin{array}{l}-0.627 \\
(0.423)\end{array}$ & $\begin{array}{l}-0.474 \\
(0.295)\end{array}$ & $\begin{array}{l}-0.474 \\
(0.295)\end{array}$ & $\begin{array}{l}-0.474 \\
(0.295)\end{array}$ & $\begin{array}{l}-0.627 \\
(0.423)\end{array}$ \\
\hline Mso & $\begin{array}{l}0.053 * * * \\
(0.015)\end{array}$ & $\begin{array}{l}0.072 * * \\
(0.029)\end{array}$ & $\begin{array}{l}0.053 * * * \\
(0.015)\end{array}$ & $\begin{array}{l}0.053 * * * \\
(0.015)\end{array}$ & $\begin{array}{l}0.053 * * * \\
(0.015)\end{array}$ & $\begin{array}{l}0.072 * * \\
(0.029)\end{array}$ \\
\hline Inst & $\begin{array}{l}-0.080^{* * *} * \\
(0.023)\end{array}$ & $\begin{array}{l}-0.241 * * \\
(0.119)\end{array}$ & $\begin{array}{l}-0.080^{* * *} \\
(0.023)\end{array}$ & $\begin{array}{l}-0.080^{* * *} * \\
(0.023)\end{array}$ & $\begin{array}{l}-0.080 * * * \\
(0.023)\end{array}$ & $\begin{array}{l}-0.241^{* *} \\
(0.119)\end{array}$ \\
\hline Growth & $\begin{array}{l}-0.005 \\
(0.057)\end{array}$ & $\begin{array}{l}-0.012 \\
(0.057)\end{array}$ & $\begin{array}{l}-0.005 \\
(0.057)\end{array}$ & $\begin{array}{l}-0.005 \\
(0.057)\end{array}$ & $\begin{array}{l}-0.005 \\
(0.057)\end{array}$ & $\begin{array}{l}-0.012 \\
(0.057)\end{array}$ \\
\hline $\mathrm{Npm}$ & $\begin{array}{l}0.090 * * \\
(0.037)\end{array}$ & $\begin{array}{l}0.136 * * \\
(0.065)\end{array}$ & $\begin{array}{l}0.090 * * \\
(0.037)\end{array}$ & $\begin{array}{l}0.090 * * \\
(0.037)\end{array}$ & $\begin{array}{l}0.090 * * \\
(0.037)\end{array}$ & $\begin{array}{l}0.136 * * \\
(0.065)\end{array}$ \\
\hline Lev & $\begin{array}{l}0.316^{* * *} \\
(0.126)\end{array}$ & $\begin{array}{l}0.382 * * \\
(0.150)\end{array}$ & $\begin{array}{l}0.316 * * \\
(0.126)\end{array}$ & $\begin{array}{l}0.316^{* * *} \\
(0.126)\end{array}$ & $\begin{array}{l}0.316^{* *} \\
(0.126)\end{array}$ & $\begin{array}{l}0.382 * * \\
(0.150)\end{array}$ \\
\hline Size & $\begin{array}{l}0.006 * * * \\
(0.002)\end{array}$ & $\begin{array}{l}0.006 * * * \\
(0.002)\end{array}$ & $\begin{array}{l}0.006 * * * \\
(0.002)\end{array}$ & $\begin{array}{l}0.006 * * * \\
(0.002)\end{array}$ & $\begin{array}{l}0.006 * * * \\
(0.002)\end{array}$ & $\begin{array}{l}0.006 * * * \\
(0.002)\end{array}$ \\
\hline _cons & $\begin{array}{l}-0.045^{*} \\
(0.023)\end{array}$ & $\begin{array}{l}-0.044 * \\
(0.022)\end{array}$ & $\begin{array}{l}-0.045^{*} \\
(0.023)\end{array}$ & $\begin{array}{l}-0.045^{*} \\
(0.023)\end{array}$ & $\begin{array}{l}-0.045^{*} \\
(0.023)\end{array}$ & $\begin{array}{l}-0.044 * \\
(0.022)\end{array}$ \\
\hline Obs. & 1242 & 1242 & 1242 & 1242 & 1242 & 1242 \\
\hline R-squared & 0.102 & 0.102 & 0.102 & 0.102 & 0.102 & 0.102 \\
\hline Hausman Test & $10.12(0.2311)$ & $10.12(0.2311)$ & $10.12(0.2311)$ & $10.12(0.2311)$ & $10.12(0.2311)$ & $10.12(0.2311)$ \\
\hline
\end{tabular}

Standard errors are in parenthesis

$* * * p<0.01, * * p<0.05, * p<0.1$

\subsection{Regression Results of Interaction Models for Dividend to Sales (Divsal)}

Table 4.6 showed results of the interaction models where the dependent variable of the study is dividend to sale ratio used as a proxy for expropriation. The explanatory variables include board gender diversity and its interaction with managerial ownership (bgd_mso), institutional ownership (bgd_inst), foreign ownership (bgd_for), net profit margin (bgd_npm), leverage (bgd_Lev) and size of firm (bgd_size) respectively. Moreover, the study also kept the main variables used in the baseline model such as managerial ownership, foreign ownership, institutional ownership, external audit quality and firm level variables such as leverage, net profit margin, growth and size.

The estimated results of the random effect models showed that size with board gender diversity has negative and significant effect on the dividend to sales ratio. These results are in line with the baseline regression model as reported in table 4.3. The interaction of the board gender diversity with size has a negative and significant coefficient with the dividend to sales ratio. However, size alone has significant 
positive effect on the dividend to sales ratio. Thus, these results suggested that in the presences of female in the corporate board mitigate the expropriating behavior in firms. These results support the main results of the study that is gender diversity minimize the corporate expropriations.

\subsection{Regression Results of Interaction Models for Dividend to Sales (Divsal)}

Standard errors are in parenthesis $* * * p<0.01$, ** $p<0.05, * p<0.1$

\section{Conclusion}

The objective of this research study is to look at the connection of corporate expropriation as the dependent variable, where dividend payout and related party loan are used as a proxy for corporate expropriation and the board gender diversity as the independent variable while control variables are external audit quality, dividend to sale, dividend to earning, directors loan, foreign ownership, managerial ownership, institutional ownership, growth, net profit margin, leverage, and size. This association has been analyzed on the basis of agency theory that whether the board gender diversity has any influence on corporate expropriation. For this purpose, the data is collected from 223 non-financial firms in Pakistan for the periods of 2009 to 2019. Fixed vs random effect regression models were used to estimate the results of the study. In this study, the descriptive, correlation, and regression are used to find the relationship between corporate expropriation and board gender diversity. According to the Hausman

\begin{tabular}{|c|c|c|c|c|c|c|}
\hline & $\begin{array}{l}\text { (MSO) } \\
\text { Divsal } \\
\end{array}$ & $\begin{array}{l}\text { (INST) } \\
\text { Divsal } \\
\end{array}$ & $\begin{array}{c}\text { (FOR) } \\
\text { Divsal } \\
\end{array}$ & $\begin{array}{l}\text { (NPM) } \\
\text { Divsal } \\
\end{array}$ & $\begin{array}{c}\text { (LEV) } \\
\text { Divsal } \\
\end{array}$ & $\begin{array}{c}\text { (Size) } \\
\text { Divsal } \\
\end{array}$ \\
\hline BGD & $\begin{array}{l}-0.008 * * \\
(0.004)\end{array}$ & $\begin{array}{l}-0.011 * * \\
(0.005)\end{array}$ & $\begin{array}{l}-0.005 * * \\
(0.002)\end{array}$ & $\begin{array}{l}-0.005^{*} \\
(0.003)\end{array}$ & $\begin{array}{l}-0.007 * * \\
(0.003)\end{array}$ & $\begin{array}{l}-0.064 * * \\
(0.031)\end{array}$ \\
\hline bgd_mso & $\begin{array}{l}0.249 * * \\
(0.117)\end{array}$ & & & & & \\
\hline bgd_inst & & $\begin{array}{l}0.120 \\
(0.241)\end{array}$ & & & & \\
\hline bgd_for & & & $\begin{array}{l}1.557 * * \\
(0.722)\end{array}$ & & & \\
\hline bgd_npm & & & & $\begin{array}{l}0.068 \\
(0.155)\end{array}$ & & \\
\hline bgd_lev & & & & & $\begin{array}{l}0.398 \\
(0.633)\end{array}$ & \\
\hline bgd_size & & & & & & $\begin{array}{l}-0.008 * * * \\
(0.002)\end{array}$ \\
\hline Eaq & $\begin{array}{l}-0.011 * * * \\
(0.001)\end{array}$ & $\begin{array}{l}-0.012 * * * \\
(0.001)\end{array}$ & $\begin{array}{l}-0.001 * * \\
(0.000)\end{array}$ & $\begin{array}{l}-0.001 * * \\
(0.000)\end{array}$ & $\begin{array}{l}-0.009 * * \\
(0.008)\end{array}$ & $\begin{array}{l}-0.007 * * \\
(0.003)\end{array}$ \\
\hline For & $\begin{array}{l}-0.018 \\
(0.062)\end{array}$ & $\begin{array}{l}-0.026 \\
(0.078)\end{array}$ & $\begin{array}{l}-0.021 \\
(0.031)\end{array}$ & $\begin{array}{l}-0.028 \\
(0.042)\end{array}$ & $\begin{array}{l}-0.474 \\
(0.295)\end{array}$ & $\begin{array}{l}-0.627 \\
(0.423)\end{array}$ \\
\hline Mso & $\begin{array}{l}0.006 * * \\
(0.003)\end{array}$ & $\begin{array}{l}0.006 * * \\
(0.003)\end{array}$ & $\begin{array}{l}0.007 * * \\
(0.003)\end{array}$ & $\begin{array}{l}0.008 * * \\
(0.003)\end{array}$ & $\begin{array}{l}0.053 * * * \\
(0.015)\end{array}$ & $\begin{array}{l}0.072 * * \\
(0.029)\end{array}$ \\
\hline Inst & $\begin{array}{l}0.034 \\
(0.037)\end{array}$ & $\begin{array}{l}0.033 \\
(0.047)\end{array}$ & $\begin{array}{l}0.019 \\
(0.015)\end{array}$ & $\begin{array}{l}0.028 \\
(0.019)\end{array}$ & $\begin{array}{l}-0.080 * * * \\
(0.023)\end{array}$ & $\begin{array}{l}-0.241 * * \\
(0.119)\end{array}$ \\
\hline Growth & $\begin{array}{l}-0.026 * \\
(0.014)\end{array}$ & $\begin{array}{l}-0.027 * \\
(0.014)\end{array}$ & $\begin{array}{l}-0.011 * * * \\
(0.004)\end{array}$ & $\begin{array}{l}-0.010 * * \\
(0.004)\end{array}$ & $\begin{array}{l}-0.005 \\
(0.057)\end{array}$ & $\begin{array}{l}-0.012 \\
(0.057)\end{array}$ \\
\hline $\mathrm{Npm}$ & $\begin{array}{l}0.033 * * \\
(0.013)\end{array}$ & $\begin{array}{l}0.037 * * * \\
(0.013)\end{array}$ & $\begin{array}{l}0.010 * * \\
(0.004)\end{array}$ & $\begin{array}{l}0.013 * * * \\
(0.004)\end{array}$ & $\begin{array}{l}0.090 * * \\
(0.037)\end{array}$ & $\begin{array}{l}0.136 * * \\
(0.065)\end{array}$ \\
\hline Lev & $\begin{array}{l}-0.062 \\
(0.067)\end{array}$ & $\begin{array}{l}-0.084 \\
(0.072)\end{array}$ & $\begin{array}{l}-0.042 * \\
(0.023)\end{array}$ & $\begin{array}{l}-0.050 * \\
(0.027)\end{array}$ & $\begin{array}{l}0.316^{* * *} \\
(0.126)\end{array}$ & $\begin{array}{l}0.382 * * \\
(0.150)\end{array}$ \\
\hline Size & $\begin{array}{l}0.005^{* * * *} \\
(0.001)\end{array}$ & $\begin{array}{l}0.005 * * * \\
(0.001)\end{array}$ & $\begin{array}{l}0.001 * * \\
(0.000)\end{array}$ & $\begin{array}{l}0.001 * * \\
(0.000)\end{array}$ & $\begin{array}{l}0.006 * * * \\
(0.002)\end{array}$ & $\begin{array}{l}0.006 * * * \\
(0.002)\end{array}$ \\
\hline _cons & $\begin{array}{l}-0.006 \\
(0.004)\end{array}$ & $\begin{array}{l}-0.010^{* *} \\
(0.005)\end{array}$ & $\begin{array}{l}0.002 \\
(0.002)\end{array}$ & $\begin{array}{l}0.000 \\
(0.002)\end{array}$ & $\begin{array}{l}-0.045^{*} \\
(0.023)\end{array}$ & $\begin{array}{l}-0.044^{*} \\
(0.022)\end{array}$ \\
\hline Obs. & 2012 & 2012 & 2012 & 2012 & 1242 & 1242 \\
\hline R-squared & 0.137 & 0.147 & 0.134 & 0.137 & 0.102 & 0.102 \\
\hline Hausman Test & $12.15(0.2052)$ & $12.15(0.2052)$ & $12.15(0.2052)$ & $12.15(0.2052)$ & $12.15(0.2052)$ & $12.15(0.2052)$ \\
\hline
\end{tabular}

test results, random effect models were considered for interpretations. The results show a negative and 
significant association of board gender diversity with corporate expropriation. Similarly, external audit quality and growth have a negative and significant while leverage has a negative and insignificant association with corporate expropriation. Other control variables such as dividend to earning, director's loan has also a negative association with corporate expropriation. The results also show that corporate expropriation has a positive association with a dividend to sale, foreign ownership, managerial ownership, institutional ownership, net profit margin, and size. The results of this study are helpful for the shareholders and regulators to know about factors that could increase the board gender diversity. Secondly, this study highlighted the role of board diversity in mitigating expropriation to the regulators, shareholders, and firm managers.

\section{References}

Abdullah, S. N., Ismail, K. N. I. K., \&Nachum, L. (2016).Does having women on boards create value?The impact of societal perceptions and corporate governance in emerging markets. Strategic Management Journal, 37(3), 466-476.

Adjaoud, F., \& Ben-Amar, W. (2010). Corporate Governance and Dividend Policy: Shareholders' Protection or Expropriation? Journal of Business Finance \& Accounting, 37(5-6), 648-667.

Agency Theory, Evolution, and Austrian Economics Alexandre Padilla *The Metropolitan State College of Denver, Department of Economics, Campus Box 77, P.O. Box 173362, Denver, CO 80217-3362. (n.d.).1-64.

Ahmed, A., Higgs, H., Ng, C., \& Delaney, D. A. (2018). Determinants of women representation on corporate boards: evidence from Australia. Accounting Research Journal, 31(3), 326-342. https://doi.org/10.1108/ARJ-11-2015-0133

Alexander, C. V., \&Ganesan, M.A study on Latest Management Governance Techniques in Indian Companies.

Ali, A., Klasa, S., Yeung, E., Adrian, T., Westerfield, M. M., Axelson, U., ...\& Marston, F. (2009). Review of Financial Studies.

Appiadjei, A., Oppong, G., \& Atta, F. N. E. (2017).Gender Diversity and Firm Performance. International Journal of Economics, Commerce and Management, V(10), 1-16.

Ashforth, B. E., \& Gibbs, B. W. (1990). The double-edge of organizational legitimation. Organization science, $1(2), 177-194$.

Becker, H. S. (1964). Personal change in adult life. Sociometry, 40-53.

Benkraiem, R., Hamrouni, A., Lakhal, F., \&Toumi, N. (2017).Board independence, gender diversity and CEO compensation.Corporate Governance (Bingley), 17(5), 845-860. https://doi.org/10.1108/CG02-2017-0027

Brammer, S., Millington, A., \&Pavelin, S. (2009). Corporate reputation and women on the board. British Journal of Management, 20(1), 17-29.

Buniamin, S., Johari, N. H., AbdRahman, N. R., \&Rauf, F. H. A. (2012). Board diversity and discretionary accruals of the top 100 Malaysia corporate governance (MCG) index company. African Journal of Business Management, 6(29), 8496-8503.

Burke, R. J. (1997). Women on corporate boards of directors: A needed resource. In Women in corporate management (pp. 37-43).Springer, Dordrecht.

Cabo, R., Gimeno, R., \& Nieto, M. (2012).Gender Diversity on European Banks' Boards of Directors.Journal of Business Ethics, 109. https://doi.org/10.1007/s10551-011-1112-6

Carter, D. A., Simkins, B. J., \& Simpson, W. G. (2003). Corporate governance, board diversity and firm value. Financial Review, 38, 33-53.

Choi, H. M., Sul, W., \& Min, S. K. (2012). Foreign board membership and firm value in Korea. Management Decision.

Claessens, S. (2006). Corporate governance and development. The World bank research observer, 21(1), 91-122.

Clarke, T. (2004). Cycles of Crisis and Regulation: the enduring agency and stewardship problems of corporate governance. Corporate Governance, 12(2), 153-161. doi:10.1111/j.1467- 
Company, P., Jensen, C., \&Meckling, H. (1976).THEORY OF THE FIRM : MANAGERIAL BEHAVIOR , AGENCY COSTS AND OWNERSHIP STRUCTURE I .305-360.

Daily, C. M., Certo, S. T., \& Dalton, D. R. (1999). A decade of corporate women: Some progress in the boardroom, none in the executive suite. Strategic management journal, 20(1), 93-100.

Daily, C. M., Certo, S. T., \& Dalton, D. R. (1999). Entrepreneurial ventures as an avenue to the top?: Assessing the advancement of female CEOs and directors in the Inc. 100. Journal of Developmental Entrepreneurship, 4(1), 19.

Davis, J. H., Schoorman, F. D., \& Donaldson, L. (1997). Davis, Schoorman, and Donaldson reply: The distinctiveness of agency theory and stewardship theory.

Denis, C., \& Huizinga, H. (2004). Are foreign ownership and good institutions substitutes? The case of non-traded equity.

Denis, D. K., \&McConnel, J. J. (2003). International Corporate Governance, 38 J. Fin. Q.

DiMaggio, P. J., \& Powell, W. W. (2000). The iron cage revisited institutional isomorphism and collective rationality in organizational fields. Economics meets sociology in strategic management, 17, 143-166.

Durnev, A., \&Guriev, S. (2011). Expropriation Risk and Firm Growth: A Corporate Transparency Channel. SSRN Electronic Journal. https://doi.org/10.2139/ssrn.1020476

Eisenhardt, K. M., The, S., Review, M., \& Jan, N. (1989). Agency Theory : An Assessment and Review Linked references are available on JSTOR for this article : Agency Theory: An Assessment and Review. 14(1), 57-74.

Fama, E. F., \& Jensen, M. C. (1983).Agency problems and residual claims. The journal of law and Economics, 26(2), 327-349.

Farashahi, M., Hafsi, T., \&Molz, R. (2005). Institutionalized norms of conducting research and social realities: a research synthesis of empirical works from 1983 to 2002. International Journal of Management Reviews, 7(1), 1-24.

Farrell, K. A., \&Hersch, P. L. (2005). Additions to corporate boards: The effect of gender. Journal of Corporate Finance, 11(1-2), 85-106. https://doi.org/10.1016/j.jcorpfin.2003.12.001

Fondas, N. (2000). Women on Boards of Directors: Gender Bias or Power Threat? Women on Corporate Boards of Directors, 171-177. doi:10.1007/978-90-481-3401-4_12 Aguado, I., Echebarria, C., \&Barrutia, J. (2011). (G) Mp r a SL framework. (46733), 6-25.

Global Investor Opinion Survey: Key Findings Global Investor Opinion Survey 2002 : Key findings. (2002). (July).

Gregory, H. J., \& Simms, M. E. (1999, October). Corporate governance: what it is and why it matters. In 9th International Anti-Corruption Conference, Kuala Lumpur.

Hamzah, A. H., \&Zulkafli, A. H. (2014).Board diversity and corporate expropriation. Procedia-Social and Behavioral Sciences, 164, 562-568.

Harris, C. K. (2014). Women directors on public company boards: Does a critical mass affect leverage? Business and Economics Faculty Publications, Paper 29. Retrieved from http://digitalcommons.ursinus.edu/bus_econ_fac/29

Harto, P. (2012). Corporate Governance And Political Connections On Wealth Expropriation Among Indonesian Business Groups (Doctoral dissertation).

Hillman, A. J., Canella, A. A., \&Paetzold, R. L. (2000). The resource dependency role of corporate governance directors: Strategic adaptation of board composition in response to environmental change. Journal of Management Studies, 37(2), 0022-2380.

Hillman, A. J., Shropshire, C., \&CannellaJr, A. A. (2007).Organizational predictors of women on corporate boards. Academy of Management Journal, 50(4), 941-952.

Hillman, A. J., Shropshire, C., \&Cannella, A. A. (2007).Organizational predictors of women on corporate boards.Academy of Management Journal, 50(4), 941-952.

https://doi.org/10.5465/AMJ.2007.26279222

Hopewell, L., McNeely, C. L., Kuiler, E. W., \&Hahm, J. O. (2009). University leaders and the public agenda: Talking about women and diversity in STEM fields. Review of Policy Research, 26(5), 589-607. 
Hyland, M. M. C., \&Marcellino, P. A. (2002).Examining gender on corporate boards: A regional study. Corporate Governance: The International Journal of Business in Society, 2(4), 24-31. https://doi.org/10.1108/14720700210447669

Ishak, R., Amran, A., Bahrain, K., \&Manaf, A. (2016).International Review of Management and Marketing Leadership Structure, Gender Diversity and Audit Quality Influence on Earnings Management in Malaysian Listed Companies.International Review of Management and Marketing |, 6(S8), 342-345. Retrieved from http:www.econjournals.com

Kesner, I. F. (1988). Directors' characteristics and committee membership: An investigation of type, occupation, tenure, and gender. Academy of Management journal, 31(1), 66-84.

Mancinelli, L., \&Ozkan, A. (2006). Ownership structure and dividend policy: Evidence from Italian firms. European Journal of Finance, 12(03), 265-282.

Means, G. C. (1933).The Modern Corporation and Private Property, by Adolf A . BerleJr .8(8).

Millstein, I. M. (1998). Corporate governance: Improving competitiveness and access to capital in global markets: A report to the OECD. OECD Publishing.

Mirza, H., Mahmood, S., Andleeb, S., \&Ramzan, F. (2012). Gender Diversity and Firm Performance: Evidence from Pakistan.

Mitton, T. (2002).A cross-firm analysis of the impact of corporate governance on the East Asian financial crisis \$.64, 215-241.

Mustafa, A. S., Che Ahmad, A., \&Chandren, S. (2017). Board diversity and audit quality: evidence from Turkey. Journal of Advanced Research in Business and Management Studies, 6(1), 50-60.

Nekhili, M., \&Gatfaoui, H. (2013). Are demographic attributes and firm characteristics drivers of gender diversity? Investigating women's positions on French boards of directors. Journal of business ethics, 118(2), 227-249.

Oatley, K., \& Johnson-Laird, P. N. (1996). The communicative theory of emotions: Empirical tests, mental models, and implications for social interaction

Peterson, C. A., \& Philpot, J. (2007). Women's roles on US Fortune 500 boards: Director expertise and committee memberships. Journal of Business Ethics, 72(2), 177-196.

Pfeffer, J. (1972). Size and composition of corporate boards of directors: The organization and its environment. Administrative science quarterly, 218-228.

Pfeffer, J., \&Salancik, G. R. (2003). The external control of organizations: A resource dependence perspective. Stanford University Press.

Pindado, J., \& De la Torre, C. (2006). The role of investment, financing and dividend decisions in explaining corporate ownership structure: Empirical evidence from Spain. European Financial Management, 12(5), 661-687.

Randoy, T., \&Oxelheim, L. (2002). The impact of foreign board membership on firm value.Lund Institute of Economic Research.

Rodriguez, J., Lawrence, E. R., \& Lawrence, E. R. (n.d.).Do Institutional Investors Avoid Women? Do Institutional Investors Avoid Women? Abstract.

Ross, B. S. A. (n.d.). The Economic Theory of Agency: The Principal â€ ${ }^{T M}$ s Problem.

Saeed, A., \&Athreye, S. (2014). Internal Capital Markets and outward Foreign Investment from India and China. International Business and Institutions after the Financial Crisis, 93-108.

Saeed, A., Belghitar, Y., \&Yousaf, A. (2016).Firm-level determinants of gender diversity in the boardrooms: Evidence from some emerging markets.International Business Review, 25(5), 10761088. https://doi.org/10.1016/j.ibusrev.2016.01.002.

Saeed, A., Sameer, M., Raziq, M. M., Salman, A., \&Hammoudeh, S. (2019). Board Gender Diversity and Organizational Determinants: Empirical Evidence from a Major Developing Country. Emerging Markets Finance and Trade, 55(8), 1803-1820. https://doi.org/10.1080/1540496X.2018.1496421.

Saito, Y. (2017). Female Board of Directors and Organisational Diversity in Japan.(November). Sarkar, J., \&Selarka, E. (2017). Women on Board and Performance of Family Firms: Evidence from India. In Ssrn. https://doi.org/10.2139/ssrn.2905587. 
Shleifer, A., \&Vishny, R. W. (1997).A survey of corporate governance. The journal of finance, 52(2), 737-783.

Singh, V., Terjesen, S., \&Vinnicombe, S. (2008). Newly appointed directors in the boardroom:: How do women and men differ?. European management journal, 26(1), 48-58.

Sulong, Z., \&Nor, F. M. (2008). Dividends, Ownership Structure and Board Governance On Firm Value: Empirical Evidences From Malaysian Listed Firm. Management \& Accounting Review (MAR), 7(2), 55-94.

Sulong, Z., \&Nor, F. M. (2008). Dividends, Ownership Structure and Board Governance On Firm Value: Empirical Evidences From Malaysian Listed Firm. Management \& Accounting Review (MAR), 7(2), 55-94.

Terjesen, S., \& Singh, V. (2008). Female Presence on Corporate Boards: A Multi-Country Study of Environmental Context. Journal of Business Ethics, 83(1), 55-63.

Ullah, H., \& Shah, A. (2016.).RELATED PARTY TRANSACTIONS AND CORPORATE GOVERNANCE MECHANISMS : EVIDENCE FROM FIRMS LISTED ON THE KARACHI. 663-680.

Upadhyay, A. (2014). Social concentration on boards, corporate information environment and cost of capital.Journal of Business Finance and Accounting, 41(7-8), 974-1001. https://doi.org/10.1111/jbfa.12083.

Yasser, Q.R. (2012). Effects of Female Directors on Firms Performance in Pakistan.

Zahra, S. A., \& Pearce, J. A. (1989). Boards of directors and corporate financial performance: A review and integrative model. Journal of management, 15(2), 291-334. 